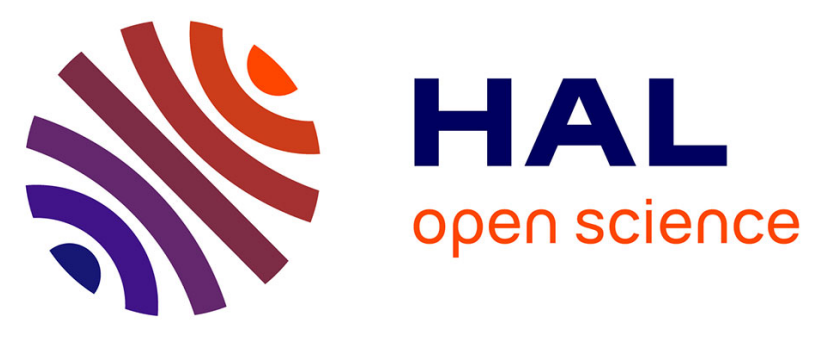

\title{
Influence of number of azo bonds and mass transport limitations towards the elimination capacity of continuous electrochemical process for the removal of textile industrial dyes
}

\author{
Jaanavee Alagesan, Mecghasri Jaisankar, Sindhu Muthuramalingam, \\ Emmanuel Mousset, Padmanaban Velayudhaperumal Chellam
}

\section{To cite this version:}

Jaanavee Alagesan, Mecghasri Jaisankar, Sindhu Muthuramalingam, Emmanuel Mousset, Padmanaban Velayudhaperumal Chellam. Influence of number of azo bonds and mass transport limitations towards the elimination capacity of continuous electrochemical process for the removal of textile industrial dyes. Chemosphere, 2021, 262, pp.128381. 10.1016/j.chemosphere.2020.128381 . hal-02993294

\author{
HAL Id: hal-02993294 \\ https://hal.science/hal-02993294
}

Submitted on 5 Dec 2020

HAL is a multi-disciplinary open access archive for the deposit and dissemination of scientific research documents, whether they are published or not. The documents may come from teaching and research institutions in France or abroad, or from public or private research centers.
L'archive ouverte pluridisciplinaire HAL, est destinée au dépôt et à la diffusion de documents scientifiques de niveau recherche, publiés ou non, émanant des établissements d'enseignement et de recherche français ou étrangers, des laboratoires publics ou privés. 


\title{
Influence of number of azo bonds and mass transport limitations
} towards the elimination capacity of continuous electrochemical process for the removal of textile industrial dyes

Jaanavee Alagesan ${ }^{1}$, MecghaSri Jaisankar', Sindhu Muthuramalingam ${ }^{1}$, Emmanuel Mousset $^{2 *}$, Padmanaban Velayudhaperumal Chellam ${ }^{{ }^{*}}$ (All authors have equally contributed)

1- Centre for Research, Department of Biotechnology, Kamaraj College of Engineering \& Technology, Madurai, Tamilnadu, India.

2- Laboratoire Réactions et Génie des Procédés, UMR CNRS 7274, Université de Lorraine, 1 rue Grandville BP 20451, 54001 Nancy cedex, France.*

\section{Accepted version}

\section{Chemosphere}

Author to whom correspondence should be addressed

\author{
V.C.Padmanaban
vcpadmanaban88@gmail.com; \\ V.C.Padmanaban
vcpadmanaban88@gmail.com; \\ Emmanuel Mousset \\ emmanuel.mousset@univ-lorraine.fr; \\ fr;
}




\section{ABSTRACT}

This study focusses on the electrochemical decomposition of synthetic azo dyes (RO16, RR120 and DR80) using stainless steel electrodes, which is efficient, cost effective and industrially driven process. The experiments were carried out in a continuous electrochemical reactor and the effects of influencing parameters (initial concentration of dye, electrolyte concentration, $\mathrm{pH}$ ) governing the process efficiency was studied. The interaction between the influencing parameters was investigated using Response Surface Methodology (RSM) and the regression value obtained for the generated model was above 0.9 for all the three dyes. The elimination capacity of electrochemical reactor was studied for the continuous removal of azo dyes with different ranges of concentration $\left(100-400 \mathrm{mg} \mathrm{L}^{-1}\right)$ and flow rate $\left(0.1-0.5 \mathrm{~L} \mathrm{~h}^{-1}\right)$. The maximum elimination capacity was obtained at a flow rate of $0.5 \mathrm{~L} \mathrm{~h}^{-1}$ for $300 \mathrm{mg} \mathrm{L}^{-1}$ of initial concentration of dye for RO16 and RR120 whereas it was $0.5 \mathrm{~L} \mathrm{~h}^{-1}$ for $400 \mathrm{mg} \mathrm{L}^{-1}$ of DR80. Further, a general dimensionless current density relation has been established for stirred tank reactor and allowed characterizing the relationship between kinetics and mass transport contributing to the overall reaction rate. The results quantitatively confirmed that the rate of electrochemical decolorization increased with the increasing initial dye concentration and flow rate due to the mass transport limitation. As newly established, the decolorization is also directly linked to the number of azo bonds.

Keywords: Azo dyes; Electrochemical process; Response Surface Methodology; Continuous mode; Elimination capacity; Dimensionless current density 


\section{INTRODUCTION}

Rapid industrialization, continuous growth of population and over exploitation of natural resources has created an imbalance in the ecosystem. It has also intensified the environmental issues associated with water, air and land. Enormous increase in the growth and development of industries created a global demand for water due to its excessive consumption as it cannot be substituted for its wide range of industrial applications. But the prevailing water crisis has created an increasing awareness on the limited access to freshwater resources. The United Nations World Water Development report released in 2018, forecasts that by the year 2050 nearly 3.6 to 4.6 billion people will be facing severe water stress.

On the other hand, due to the negligence in the implementation of stringent policies towards industrial water treatment as well as lack of efficient technologies in large scale has created an another dimension of water stress in terms of quality. Large amount of water and chemicals are consumed by the textile hubs for the wet processing of materials and simultaneously significant volume of contaminated effluent is discharged (Hasanbeigi and Price, 2015). Consumption of such contaminated resources will have a direct impact on the health status of the human. Among such micropollutants, azo dyes creates a major havoc to the environment and the public health because of their toxic nature due to the presence of aromatic amine groups (Holkar et al., 2016). Schneider et al., reported on the mutagenic nature of textile dyes by studying the genotoxic activity of azo dyes (Schneider et al., 2004). Additionally, allergic contact dermatitis and respiratory diseases are known to be caused by textile dyes (Gürses et al., 2016). However, azo dyes are predominantly used by majority of the Indian textile industries as it is economic and also acts as an effective chromophore. The available literature demonstrates an extensive number of treatment methodologies involving physical methods like adsorption (Brahmi et al., 2019; Shahnaz et al., 2020a, 2020b; Sharma et al., 2020), chemical (Jegan Durai et al., 2020) and biological processes (Padmanaban et al., 2016) 
as well as some of the new emerging techniques like advanced oxidation process and photoelectrocatalysis (Aquino et al., 2013). Though there are plethora of research publications on developing process for the decolorization of textile dyes, still in industries those technologies are not in practice. Most of the developed process in the laboratory conditions fails during scale up or during experimenting with real industrial effluent. The possible reasons could be: (a) process development using $\mathrm{pH}$ indicators and stains; (b) the industrial effluent is a complex mixture of different classes of dyes like monoazo, diazo, polyazo, Reactive and Direct; (c) the industrial effluent $\mathrm{pH}$ is alkaline in nature; (d) high salt concentration in the industrial effluent; (e) large volumes to handle at short time, i.e. high treatment capacity requirement. To face these multiple constraints, developing a cost-effective technology remain a challenge. A streamlined approach need to be followed during the process development for the decolorization or degradation of dyes by using chemical engineering tools and methodology.

Over the past decades, electrochemical processes have gained an increasing interest among the environment researchers in treating various micro and macro pollutants from various industries and especially dyes (Brillas and Martínez-Huitle, 2015). In direct electrolysis, at the anodic surface, direct exchange of electrons takes place with the pollutants, thereby it destabilises or degrade the pollutants whereas in indirect electrolysis, the exchange of electrons with the pollutants is mediated by active species. The chain of redox catalysis takes place from anodic surface to pollutants through series of electroactive species generated reversibly or irreversibly (Panizza and Cerisola, 2009). Non-active anodes can even produce physisorbed hydroxyl radicals $\left({ }^{\circ} \mathrm{OH}\right)$ that are available for indirect oxidation of the majority of organic compounds that can enhance the degradation and mineralization efficiency (Mousset et al., 2018). Upon the superiority of this mechanism, numerous articles proposed their implementation for dyes elimination (Brillas and Martínez-Huitle, 2015). However, such 
advanced electro-oxidation processes involve expensive materials such as boron-doped diamonds (BDD) materials that proved to be currently the best option for long-term and real applications (Nidheesh et al., 2019). Contrastingly, when using active anode, i.e. without available ${ }^{\bullet} \mathrm{OH}$ for indirect oxidation, the electrochemical degradation of dyes wastewater could still occur, mainly by electron transfer reaction coupled with a dissociation chemisorption step (Mohan et al., 2007). The efficiency of direct anodic oxidation of dyes benefits from the presence of several functional groups (e.g. azo bonds) on their molecules that make them electroactive for direct electron transfer (Michaelis, 1935). Moreover, the advantage of active anodes (e.g. graphite, stainless steel) is their low cost compared to non-active materials, while their efficiency towards dyes removal could remain still competitive in terms of cost-efficiency (Mohan et al., 2007). This type of oxidation has been further tested as a viable alternative for the degradation of textile dyes owing to their cost-effectiveness, eco-friendly nature and ability to produce less sludge (Bassyouni et al., 2017). Moreover, electrocoagulation process has also demonstrated to be effective for dye wastewater treatment by using cheap aluminium or iron based- sacrificial anode for coagulant generation (Arslan-Alaton et al., 2008). A synergy by using a non-active anode such as stainless steel that can act both as sacrificial anode and as a role of direct electro-oxidation could be therefore interesting (Arslan-Alaton et al., 2008). The presence of chloride at sufficient high concentration $\left(>0.6 \mathrm{~g} \mathrm{~L}^{-1}\right)$ has shown to favour both the mediated oxidation with active chlorine $\left(\mathrm{Cl}_{2}, \mathrm{ClOH}\right)$ and the electrocoagulation mechanism with iron-based anode (Hakizimana et al., 2017). Since dye effluents contain high content of chloride, this could be interesting to combine electro-oxidation with electrocoagulation for such application (Hakizimana et al., 2017).

In order to proceed with this approach, better understanding on the electrochemical process, the influence of molecular structure of dyes as well as the competition study between charge transfer and mass transport is required for such heterogeneous process. The main objective of 
this study is therefore to provide answers to these issues for the first time, by developing a continuous stirred electrochemical reactor for the decolorization of textile dyes having different number of azo bonds. An optimization of the technology is first proposed, by using One Variable At a Time approach (OVAT) and Response Surface Methodology (RSM) in batch mode. Then the effectiveness of the process in terms of elimination capacity, current efficiency and energy consumption has been assessed under continuous mode. A general expression of dimensionless current density is suggested for stirred tank cell design, as a way of better quantitatively describe the competitiveness between charge transfer and mass transport phenomena.

\section{MATERIALS AND METHODS}

\subsection{Chemicals used}

In this study, industrially used azo bond containing dyes of different classes were used. Reactive Orange 16 (RO16), Reactive Red 120 (RR120) and Direct Red 80 (DR80) were taken as the model dyes and were procured from Sigma-Aldrich, India. The physico-chemical properties of the dyes are given in Table SM-1. Other chemicals such as sodium chloride $(\mathrm{NaCl})$, hydrochloric acid $(\mathrm{HCl})$ and sodium hydroxide $(\mathrm{NaOH})$ of laboratory grade were purchased from HiMedia Laboratories, India. Simulated dye solution was prepared by dissolving the industrially used azo dyes (RO16, RR120 and DR80) in aqueous medium and was diluted to the specified concentration as released in the industrial effluent. Sodium chloride is used as the supporting electrolyte in the process, since $\mathrm{Cl}^{-}$is a predominant inorganic species at high concentration in most of dyes effluents (Hakizimana et al., 2017). The pH of the solution was adjusted using $1 \mathrm{~N} \mathrm{NaOH}$ (basic) and $1 \mathrm{~N} \mathrm{HCl}$ (acidic). 


\subsection{Electrochemical reactor and dye decolorization analysis}

A cylindrical lab scale reactor made up of borosilicate glass with a net volume of 1500 $\mathrm{cm}^{3}$ was used for the electrochemical decolorization of synthetic wastewater. Stainless steel electrodes (both anode and cathode) (Kristeel brand) with an immersed surface area of $17 \mathrm{~cm}^{2}$ were used. The inter-electrode distance between the anode and cathode was fixed as $4 \mathrm{~cm}$ for all the experimental runs. For all the experiments the voltage was maintained within the ranges of $3.8-4.0 \mathrm{~V}$ (previous unpublished data) using a variable DC power supply (Scientech Technologies), corresponding to an average applied current density of $47 \mathrm{~mA} \mathrm{~cm}{ }^{-2}$. These values fall in the range of optimal current density found in a previous study using stainless steel sacrificial anode for dye wastewater (Arslan-Alaton et al., 2008). A magnetic stirrer (Remi) was used for the stirring of solutions $(100 \mathrm{rpm})$. The experiments were conducted at room temperature. Block diagram of the electrochemical reactor is shown in the graphical abstract. Sludge were also generated during the electrocoagulation mechanism at the stainless steel anode, according to Eq. (1) and Eq. (2) (Arslan-Alaton et al., 2008):

$$
\begin{aligned}
& 2 \mathrm{Fe}(\mathrm{s}) \rightarrow 2 \mathrm{Fe}^{2+}(\mathrm{aq})+4 \mathrm{e}^{-} \\
& 2 \mathrm{Fe}^{2+}(\mathrm{aq})+5 \mathrm{H}_{2} \mathrm{O}+1 / 2 \mathrm{O}_{2} \rightarrow 2 \mathrm{Fe}(\mathrm{OH})_{3}(\mathrm{~s})+4 \mathrm{H}^{+}
\end{aligned}
$$

The sludge was then separated using centrifugation at $8000 \mathrm{rpm}$ for $5 \mathrm{~min}$. The decolorization of dyes was monitored by change in absorbance and measured $\lambda_{\max }$ as specified in the Table SM-1 using a UV-Visible spectrophotometer (Eppendorf, Germany). The percentage of decolorization and concentration of dye decolorized were calculated based on Eq. (3):

$$
\% \text { removal in terms of decolorization }=\left(\frac{A_{i}-A_{t}}{A_{i}}\right) \times 100
$$

$$
\text { where } A_{i} \text { and } A_{t} \text { are absorbance at initial time and absorbance at time } t \text {, respectively. }
$$




\subsection{Batch process optimization - OVAT}

A batch mode was chosen as a preliminary step to determine the effects of $\mathrm{pH}$, electrolyte concentration and initial concentration of dye on the electrochemical decolorization of synthetic wastewater. This investigation was carried out in order to determine the optimum operating conditions for achieving maximum percentage of dye decolorization. For better understanding of the influencing factors, individual set of experiments were performed for all the three dyes (RO16, RR120 \& DR80) within the specified range of reaction conditions (pH: 3.0 - 11.0, electrolyte concentration: from 0.1 to $0.5 \mathrm{M}$ and initial concentration of dye: from 100 to $500 \mathrm{mg} \mathrm{L}^{-1}$ ). Working volume of $500 \mathrm{~mL}$ was fixed for all experiments. The treated samples collected at periodic time intervals were subjected to centrifugation (5000 rpm, $5 \mathrm{~min}$ ) for separating the sludge particles generated during the electrochemical process.

\subsection{Batch process optimization - RSM}

$\mathrm{RSM}$ is one of the structured statistical methods for designing experiments, generating models, understanding variable effects on the response and also for improving the response using optimal conditions (Amani-ghadim et al., 2013). In this study, modified face centred central composite design (CCF) with alpha value 1.0 was used to analyze the interaction between the influencing parameters and also on the selection of optimum variables for maximizing the decolorization of synthetic azo dyes. Initial concentration of dye, $\mathrm{pH}$ and reaction time for the electrochemical process were the selected factors to be studied using RSM. In case of direct dyes, $\mathrm{pH}$ was excluded as it had no significant effects on decolorization. The experimental design for the decolorization of azo dyes is shown in Table 1 . 
Table 1 Experimental design for decolorization of azo dyes by RSM-CCF

a) Reactive dyes (RO16 and RR120)

\begin{tabular}{|c|c|c|c|c|c|}
\hline Factor & Units & $\begin{array}{c}\text { Low } \\
\text { Actual }\end{array}$ & High Actual & Mean & $\begin{array}{l}\text { Std. } \\
\text { Dev }\end{array}$ \\
\hline $\begin{array}{c}\mathbf{A}=\text { Initial concentration } \\
\text { of dye }\end{array}$ & $\mathrm{mg} \mathrm{L}^{-1}$ & 100 & 1000 & 550 & 318.29 \\
\hline $\mathbf{B}=\mathrm{pH}$ & - & 3.0 & 11.0 & 7.0 & 2.828 \\
\hline $\mathbf{C}=$ Time & $\min$ & 5 & 15 & 10 & 3.536 \\
\hline Response & Units & Model & Transformation & Mean & Ratio \\
\hline $\begin{array}{c}\mathbf{Y}_{1}=\text { Concentration of } \\
\text { RO16 decolorized }\end{array}$ & $\mathrm{mg} \mathrm{L}^{-1}$ & Quadratic & Base $10 \log$ & 204.52 & 57.496 \\
\hline $\begin{array}{l}\mathbf{Y}_{2}=\text { Concentration of } \\
\text { RR120 decolorized }\end{array}$ & $\mathrm{mg} \mathrm{L}^{-1}$ & Quadratic & Inverse Sq Rt & 265.27 & 12.89 \\
\hline
\end{tabular}

b) Direct dye (DR80)

\begin{tabular}{cccccc}
\hline Factor & Units & Low & High Actual & Mean & Std. \\
& & Actual & & Dev \\
\hline $\begin{array}{c}\text { A = Initial concentration } \\
\text { of dye }\end{array}$ & $\mathrm{mg} \mathrm{L}^{-1}$ & 100 & 1000 & 550 & 318.29 \\
$\mathbf{B}=$ Time & min & 5 & 15 & 10 & 3.536 \\
Response & Units & Model & Transformation & Mean & Ratio \\
\hline Y3= Concentration of & mg L & Quadratic & Power & 492.79 & 10.88 \\
DR80 decolorized & & & & \\
\hline
\end{tabular}




\subsection{Decolorization of azo dyes - Continuous process}

The decolorization of the azo dyes was monitored during continuous electrochemical treatment. The simulated dye solution was pumped into the continuous reactor via peristaltic pump with a predetermined flow rate (ranging from 0.1 to $0.5 \mathrm{~L} \mathrm{~h}^{-1}$ ). For all the experimental runs, hold-up volume of the reactor was maintained as $700 \mathrm{~mL}$ by providing similar flow rates at both the inlet and outlet. This experiment was performed with various dye concentrations (100, 200, 300 and $400 \mathrm{mg} \mathrm{L}^{-1}$ ) at $\mathrm{pH} 11.0$ for all the three dyes. The electrolyte (salt) concentration was maintained using $0.5 \mathrm{M} \mathrm{NaCl}$. The reactor efficiency was calculated by the elimination capacity for different inlet loading rates using Eq. (4) and Eq. (5).

$$
\text { Inlet loading rate }\left(\mathrm{mg}(\mathrm{Lh})^{-1}\right)=\frac{C_{i n} Q}{V}
$$

$$
\text { Elimination capacity }\left(\mathrm{mg}(\mathrm{Lh})^{-1}\right)=\frac{\left(C_{\text {in }}-C_{\text {out }}\right) Q}{V}
$$

where $\mathrm{C}_{\mathrm{in}}$ and $\mathrm{C}_{\mathrm{out}}$ are inlet and outlet concentration of dye respectively, $\mathrm{Q}$ is the volumetric flow rate $\left(\mathrm{L} \mathrm{h}^{-1}\right)$ and $\mathrm{V}$ is the holdup volume of the reactor $(\mathrm{L})$.

\section{RESULTS AND DISCUSSION}

\subsection{Characterization of dye - Changes in absorption spectra}

The characterization and the suitability of the kinetics of dye decolorization assessment by the spectrophotometric method is carried out as a preliminary step. $100 \mathrm{mg} \mathrm{L}^{-1}$ of simulated solution was prepared individually for all the three dyes (Operating conditions: $\mathrm{pH} 11.0,0.5 \mathrm{M}$ $\mathrm{NaCl}, 4 \mathrm{~V}$ ) and subjected to electrochemical process for $10 \mathrm{~min}$. The result of changes in absorption spectra of samples before decolorization $\left(0^{\text {th }} \mathrm{min}\right)$ and after decolorization is shown in the Fig. SM-1. The UV-Visible spectrophotometric analysis of non-decolorized RO16 dye shows two prominent peaks at $490 \mathrm{~nm}$ and $390 \mathrm{~nm}$, RR120 shows at $510 \mathrm{~nm}$ and $290 \mathrm{~nm}$ and DR80 shows at $540 \mathrm{~nm}$ and $290 \mathrm{~nm}$ respectively. The peak in the visible region corresponds to the conjugated structure of azo bond (chromophores) and peak in the UV region is attributed to 
the aromatic structure (Padmanaban et al., 2018). The dye solutions subjected to electrochemical process lost its colour and it is confirmed from the disappearance of prominent peaks without apparition of interfering peaks that could come from the matrix and intermediates generated with electrolysis time. It further confirms the reliability to use this method for the following batch and continuous mode studies, by considering that the absorbance measured at wavelength giving maximal absorbance of the dye was link only to the concentration of the studied dye and not to any other species that could absorb also at this wavelength.

\subsection{Batch process optimization - OVAT}

Most textile industries produce effluent that need to be neutralized from highly alkaline $\mathrm{pH}$ prior to discharge or reuse. With respect to effluent treatment plants, the $\mathrm{pH}$ of the influent coming to the plants may be of diverse range of $\mathrm{pH}$ and it has to be brought near to the $\mathrm{pH}$ of the process employed in the treatment plant. The effect of $\mathrm{pH}(3.0-11.0)$ on the process of decolorization was studied through five different batch experiments at $100 \mathrm{mg} \mathrm{L}^{-1}$ of initial concentration of dyes (RO16, RR120 \& DR80) with $0.5 \mathrm{M}$ of electrolyte concentration at $4 \mathrm{~V}$. At $6^{\text {th }} \mathrm{min}$, the process of decolorization comes to an equilibrium. Table 2 depicts the percentage of dye decolorization at $6^{\text {th }} \min$ for different $\mathrm{pH}$. For the reactive and direct dyes, percentage of decolorization increased while moving from acidic condition to alkaline condition. Close examination of the results indicates that nearly $100 \%$ of decolorization was achieved at $\mathrm{pH}$ 11.0. At $\mathrm{pH}>7.5$, the rate of $\mathrm{Fe}^{2+}$ oxidation into $\mathrm{Fe}(\mathrm{OH})_{2}$ (s) (Eq. (6)) is increased, which subsequently increase the production of $\mathrm{Fe}(\mathrm{OH})_{3}(\mathrm{~s})$ (Eq. (7)) and can therefore increase the electrocoagulation efficiency (Hakizimana et al., 2017).

$$
\begin{aligned}
& \mathrm{Fe}^{2+}+2 \mathrm{OH}^{-} \rightarrow \mathrm{Fe}(\mathrm{OH})_{2}(\mathrm{~s}) \\
& 4 \mathrm{Fe}(\mathrm{OH})_{2}(\mathrm{~s})+\mathrm{O}_{2}+2 \mathrm{H}_{2} \mathrm{O} \rightarrow 4 \mathrm{Fe}(\mathrm{OH})_{3}(\mathrm{~s})
\end{aligned}
$$


Knowing that the $\mathrm{pH}$ of majority of textile wastewaters (cotton fibre) lies within the range 8.012.0 (Correia et al., 1994), $\mathrm{pH}$ adjustment won't be required to operate at optimal $\mathrm{pH}$. Hence, $\mathrm{pH} 11.0$ is considered to be the optimum $\mathrm{pH}$ for the decolorization of azo dyes by electrochemical process with the employment of stainless steel electrodes.

The effect of electrolyte was studied at various concentrations ranging from 0.1 to $0.5 \mathrm{M}$ $\mathrm{NaCl}$. From Table 2, it is shown that the percentage of decolorization for the solution with an initial dye concentration of $100 \mathrm{mg} \mathrm{L}^{-1}$ and $\mathrm{pH} 11.0$ increases with the increasing electrolyte concentration. Eq. (8) and Eq. (9) shows that the active chlorine species $\left(\mathrm{Cl}_{2}, \mathrm{ClOH}\right)$ (Mousset et al., 2020)) generated from $\mathrm{Cl}^{-}$oxidation could have contributed in the indirect electrochemical process of azo dyes:

$$
\begin{aligned}
& 2 \mathrm{Cl}^{-} \rightarrow \mathrm{Cl}_{2}+2 \mathrm{e}^{-} \\
& \mathrm{Cl}_{2}+\mathrm{H}_{2} \mathrm{O} \rightarrow \mathrm{ClOH}+\mathrm{Cl}^{-}+\mathrm{H}^{+}
\end{aligned}
$$

Similar kinds of results have been also reported with active anode that was not made of mixed metal oxide but with a carbon-based material (Mousset et al., 2020). In addition, the formation of active chlorine has shown to increase the formation of $\mathrm{Fe}^{3+}$ (Eq. (10)), that then enhance the electrocoagulation process (Hakizimana et al., 2017):

$$
2 \mathrm{Fe}^{2+}+2 \mathrm{HOCl} \rightarrow 2 \mathrm{Fe}^{3+}+2 \mathrm{OH}^{-}+\mathrm{Cl}_{2}
$$

For reactive dyes, $0.5 \mathrm{M} \mathrm{NaCl}$ was the optimum electrolyte concentration for achieving $100 \%$ of dye decolorization, while the maximum of decolorization was already reached at 0.3M with DR80. Therefore, the supporting electrolyte concentration was fixed at $0.5 \mathrm{M}$ for the subsequent experiments as the real time textile industrial effluent has a mixture of reactive and direct dyes. This is further representative of the range of concentrations given in real dye wastewater (Arslan-Alaton et al., 2008). 
Table 2 Decolorization of azo dyes - One Variable At a Time approach: Effect of $\mathrm{pH}$, Effect of Electrolyte Concentration $(\mathrm{NaCl})$, Effect of Initial Concentration of dye

\begin{tabular}{cccc}
\hline $\mathbf{p H}$ & \multicolumn{3}{c}{$\%$ of dye decolorized } \\
\cline { 2 - 4 } & RO16 & RR120 & DR80 \\
\hline 3.0 & 53 & 79 & 84 \\
\hline 5.0 & 57 & 89 & 90 \\
\hline 7.0 & 61 & 85 & 98 \\
\hline 9.0 & 87 & 93 & 100
\end{tabular}

Initial conc.of dye $=100 \mathrm{mg} \mathrm{L}^{-1} ;$ Electrolyte concentration $=0.5 \mathrm{M}$;

Voltage $=4 \mathrm{~V} ;$ Run time $=6 \mathrm{~min}$

\begin{tabular}{cccc}
\hline \multirow{2}{*}{$\begin{array}{c}\text { Electrolyte Concentration } \\
(\mathbf{M})\end{array}$} & $\mathbf{3}$ & \% of dye decolorized \\
\cline { 2 - 4 } & 18 & RR120 & DR80 \\
\hline 0.1 & 21 & 9 & 39 \\
\hline 0.2 & 23 & 33 & 72 \\
\hline 0.3 & 47 & 83 & 100 \\
\hline 0.4 & 90 & 100 & 100 \\
\hline 0.5 & & 83 & \\
\hline
\end{tabular}

Initial concentration of dye $=100 \mathrm{mg} \mathrm{L}^{-1} ; \mathrm{pH}=11.0$;

Voltage $=4 \mathrm{~V} ;$ Run time $=6 \mathrm{~min}$

\begin{tabular}{cccc}
\hline $\begin{array}{c}\text { Initial Concentration of dye } \\
\left(\mathbf{m g ~ L}^{-\mathbf{1}}\right)\end{array}$ & \multicolumn{3}{c}{ Concentration of dye decolorized $\left(\mathbf{m g ~}_{\mathbf{~}}^{\mathbf{- 1}}\right)$} \\
\cline { 2 - 4 } & $\mathbf{R O 1 6}$ & $\mathbf{R R 1 2 0}$ & $\mathbf{D R 8 0}$ \\
\hline 100 & 100 & 99 & 100 \\
\hline 200 & 90 & 115 & 199 \\
\hline 300 & 117 & 119 & 300 \\
\hline 400 & 107 & 122 & 391 \\
\hline 500 & 164 & 240 & 488 \\
\hline
\end{tabular}

$p H=11.0 ;$ Electrolyte concentration $=0.5 \mathrm{M}$;

Voltage $=4 \mathrm{~V} ;$ Run time $=6 \mathrm{~min}$

281 The effect of initial concentration of dye on the decolorization of azo dyes by

282 electrochemical process was studied by varying the concentrations from 100 to $500 \mathrm{mg} \mathrm{L}^{-1}$.

283 The results from Table 2 explains the decolorization potential of the process with respect to

284 different dyes. The concentration of dye decolorized increased with increase in the

concentration of azo dyes. At high initial concentration of dye $\left(500 \mathrm{mg} \mathrm{L}^{-1}\right), 33 \%\left(164 \mathrm{mg} \mathrm{L}^{-1}\right)$ 
of RO16 and 48\% (240 mg L-1) of RR120 were decolorized, whereas 97\% of DR80 (488 $\mathrm{mg} \mathrm{L}^{-}$

287

288

${ }^{1}$ ) was removed. From this study, it is interesting to note that as the complexity of dye increases with respect to number of azo bonds, the kinetics of decolorization is raising, as further discussed in section 3.4.

In addition, the amount of generated sludge was around $5.1 \mathrm{~g} \mathrm{~h}^{-1}$ in optimal condition, which is not negligible and highlighted the contribution of electrocoagulation mechanism in the removal efficiency. Still, the amount of sludge produced was 3 times less than with aluminium sacrificial anode in another study to reach complete colour removal (Arslan-Alaton et al., 2008).

\subsection{Batch process optimization - RSM}

\subsubsection{Experimental design and statistical analysis}

The effect of interaction between the influencing factors on the decolorization of the azo dyes (RO16, RR120, DR80) by electrochemical process and the design parameters based on the RSM-CCF are shown in Eqs. (11) - (13). Based on RSM designs for all the three dyes, the data were fitted into the second order polynomial equation and the empirical relationship between the dependent and independent parameters involved in the decolorization of dyes were established.

Concentration of RO16 dye decolorized $=+228.02+74.27 \mathrm{~A}+56.58 \mathrm{~B}+78.00 \mathrm{C}+27.26 \mathrm{AB}+$ $52.51 \mathrm{AC}+8.26 \mathrm{BC}-38.24 \mathrm{~A}^{2}-25.80 \mathrm{~B}^{2}-47.77 \mathrm{C}^{2}$

Concentration of $R R 120$ dye decolorized $=+323.44+122.31 \mathrm{~A}+53.32 \mathrm{~B}+97.87 \mathrm{C}+46.98 \mathrm{AB}$

$+77.02 \mathrm{AC}+26.21 \mathrm{BC}-108.59 \mathrm{~A}^{2}+16.03 \mathrm{~B}^{2}-23.76 \mathrm{C}^{2}$

Concentration of DR80 dye decolorized $=+549.41+360.54 \mathrm{~A}+99.24 \mathrm{~B}+123.16 \mathrm{AB}-$ $47.69 \mathrm{~A}^{2}-74.99 \mathrm{~B}^{2}$ 
Box-Cox plots and diagnostic plots for RO16, RR120 and DR80 are given in the supplementary data Fig. SM-2, SM-3 and SM-4 respectively. The Box-Cox transformation has been employed to improve the normality of residuals and the plots suggested a transformation in all the models: Base 10 logarithmic transformation for RO16, Inverse square root transformation for RR120, Power transformation for the DR80. The transformed and reduced model equations are given in Eqs. (14) - (16).

$\log 10($ Concentration of dye decolorized $)=+2.32+0.30 A+0.29 B+0.36 C-0.18 B C-0.29 B^{2}$

$-0.23 C^{2}$

1.0/Sqrt(Concentration of dye decolorized) $=+0.055-0.024 \mathrm{~A}-6.946 \mathrm{E}-003 \mathrm{~B}-0.014 \mathrm{C}+$ $3.863 \mathrm{E}-003 \mathrm{BC}+0.024 \mathrm{~A}^{2}+8.460 \mathrm{E}-003 \mathrm{C}^{2}$

$($ Concentration of dye decolorized $) 0.5=+23.40+9.32 \mathrm{~A}+1.92 \mathrm{~B}+2.29 \mathrm{AB}-3.52 \mathrm{~A}^{2}-1.52$ $\mathrm{B}^{2}$

Analysis of variance (ANOVA) for the RSM models of all the three dyes are consolidated in the Table 3 and supplementary data are shown in the Table SM-2, Table SM-3 and Table SM-4. The significance of each coefficient can be determined by the F-value and pvalues. The effect on the response increases with larger magnitude of F-values and smaller Pvalues. The P-Value of models generated for all the three dyes is less than 0.0001 and this indicates the significance of the parameters in the model. From the results, it was observed that for the decolorization of RO16, three linear terms (A, B, C), two quadratic terms $\left(\mathrm{B}^{2}, \mathrm{C}^{2}\right)$ and an interactive term (BC) are determining, whereas for the decolorization of RR120, three linear terms $(\mathrm{A}, \mathrm{B}, \mathrm{C})$, two quadratic terms $\left(\mathrm{A}^{2}, \mathrm{C}^{2}\right)$ and an interactive term $(\mathrm{BC})$ are significant. For all the three dyes, diagnostic plots such as predicted versus experimental helps to judge the adequacy and significance of the model. Normality of the residuals is determined using the normal probability plot. In this plot, the distribution of the residuals lies close to the trend lines and this shows minimum disperse effect. Though the lack of fit in the model is significant for 
RO16 and DR80, all the centre point experiments are performed independently for all the three dyes to study the fitness of the model with respect to other error analysis parameters which suggest the model is fit in respective transformations (Muniyasamy et al., 2020).

Table 3 CCF Model parameters for the decolorization of azo dyes from the Analysis of Variance

\begin{tabular}{lccc} 
Parameters & RO16 & RR120 & DR80 \\
\hline Model (P-value) & $<0.0001$ & $<0.0001$ & $<0.0001$ \\
\hline Significant Parameters & $\mathrm{A}, \mathrm{B}, \mathrm{C}$, & $\mathrm{A}, \mathrm{B}, \mathrm{C}$, & $\mathrm{A}, \mathrm{B}, \mathrm{AB}$, \\
$\&$ Interactions & $\mathrm{BC}, \mathrm{B}^{2}, \mathrm{C}^{2}$ & $\mathrm{BC}, \mathrm{A}^{2}, \mathrm{C}^{2}$ & $\mathrm{~A}^{2}, \mathrm{~B}^{2}$ \\
\hline $\mathrm{R}^{2}$ & 0.9277 & 0.9856 & 0.9879 \\
\hline Adjacent $\mathrm{R}^{2}$ & 0.8943 & 0.9790 & 0.9792 \\
\hline Adequate Precision & 20.32 & 40.365 & 32.645 \\
\hline Coefficient of variation $(\%)$ & 7.74 & 5.34 & 4.97
\end{tabular}

\subsubsection{Analysis of response surface - Operational parameters}

341 The interactive effects between operational parameters are explained by two dimensional

342 (contour) and three dimensional plots as shown in Fig. 1.

Interactive effects of $\mathrm{pH}$ and time

344 The interactive effects between $\mathrm{pH}$ and time are significant in the decolorization of reactive dyes (RO16, RR120). From the contour plot of RO16 (Figs. 1a and 1b), it can be interpreted that maximum concentration of dye decolorization was obtained at alkaline $\mathrm{pH}$ and at a reaction time for about $15 \mathrm{~min}$. In the case of RR120 (Figs. 1c and 1d), at $\mathrm{pH} 11.0$ the concentration of dye decolorization increased from 223 to $494 \mathrm{mg} \mathrm{L}^{-1}$ with respect to the 

maximized the concentration of dye decolorization.

a

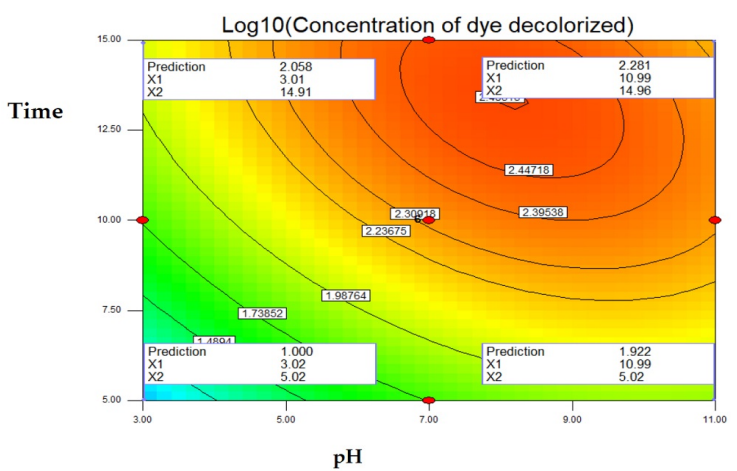

$\mathrm{c}$

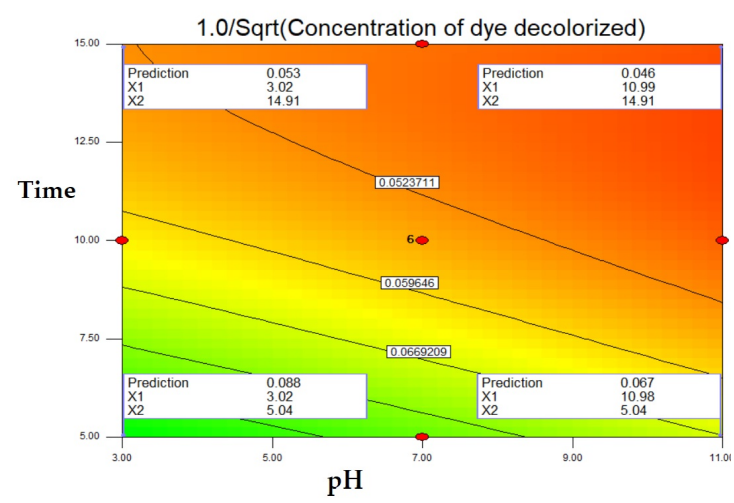

$\mathrm{e}$

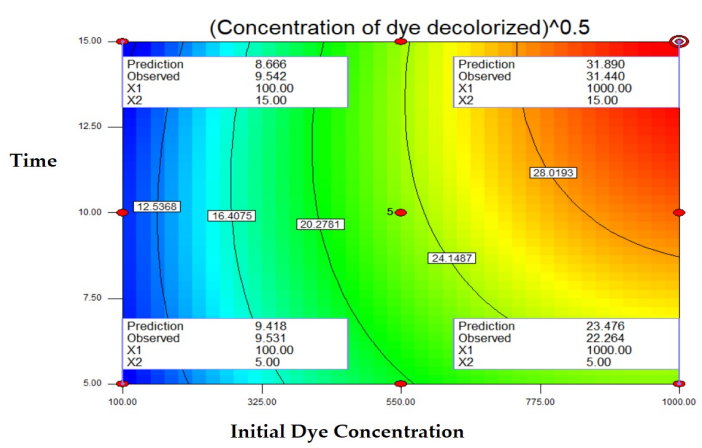

b

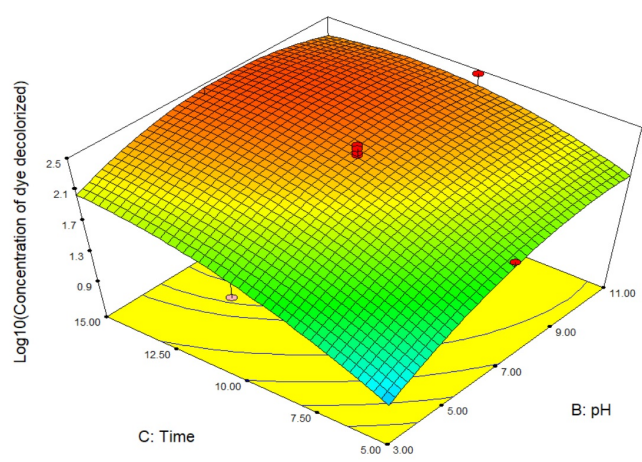

d

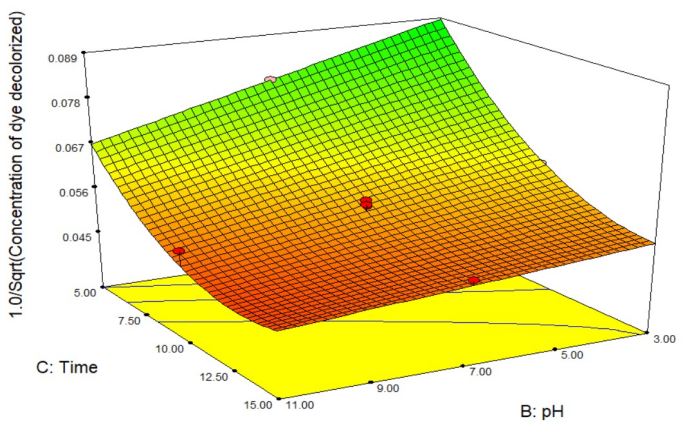

f

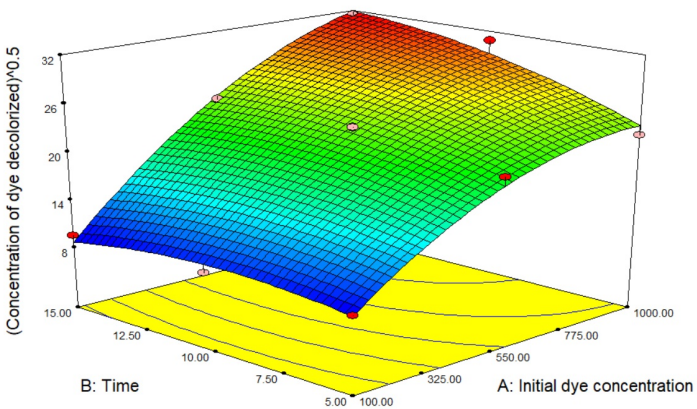

Fig. 1 CCF based Contour 2D and 3D Response surface plots: RO16 (a\&b), RR120 (c\&d) and DR80 (e\&f) 


\section{Interactive effects of initial concentration of dye and time}

The interactive effects between initial concentration of dye and time are significant in the decolorization of DR80 (Figs. 1e and 1f). Maximum concentration of dye decolorization was obtained with an increase in both the initial concentration of dye and time. The concentration of dye decolorized increased from 703 to $989 \mathrm{mg} \mathrm{L}^{-1}$ during 10 to $15 \mathrm{~min}$ with an increase in the initial concentration of dye from 550 to $1000 \mathrm{mg} \mathrm{L}^{-1}$.

\subsection{Electrochemical treatment of azo dyes under continuous mode}

The elimination capacity of continuous electrochemical treatment was studied for all the three dyes with different concentrations $\left(100-400 \mathrm{mg} \mathrm{L}^{-1}\right)$, at varied flow rates $(0.1-0.5 \mathrm{~L}$ $\left.\mathrm{h}^{-1}\right)$. The removal efficiency and elimination capacity of RO16, RR120 \& DR80 respectively at $9^{\text {th }}$ min was shown in the Table SM-5. The reactor efficiency was calculated using the inlet loading rate. The results are compared based on the reaction time. In the case of $100,200 \&$ $300 \mathrm{mg} \mathrm{L}^{-1}$ of RO16 dye concentration, the elimination capacity increased with the increase in the inlet loading rate. For $300 \mathrm{mg} \mathrm{L}^{-1}$ of RO16 with an inlet loading rate of $214 \mathrm{mg}(\mathrm{L} \mathrm{h})^{-1}$, the elimination capacity obtained was $113 \mathrm{mg}(\mathrm{L} \mathrm{h})^{-1}(\sim 52 \%$ of inlet loading rate is eliminated) with residence time of $0.531 \mathrm{~min}$. This was observed to be the maximum elimination capacity for RO16. Similar pattern was observed in RR120. For $300 \mathrm{mg} \mathrm{L}^{-1}$ of RR120 with an inlet loading rate of $214 \mathrm{mg}(\mathrm{Lh})^{-1}$, the elimination capacity obtained was $159 \mathrm{mg} \mathrm{L}^{-1} \mathrm{~h}^{-1}(\sim 74 \%$ of inlet loading rate is eliminated) with residence time of $0.377 \mathrm{~min}$. Elimination capacity decreased in the different flow rates of both the reactive dyes (RO16 and RR120) at $400 \mathrm{mg} \mathrm{L}^{-}$ 1. Interestingly, the maximum elimination capacity of DR 80 was observed at $0.5 \mathrm{~L} \mathrm{~h}^{-1}$ of 400 $\mathrm{mg} \mathrm{L}^{-1}$ concentration. $99 \%$ of inlet loading rate $\left(280 \mathrm{mg}(\mathrm{Lh})^{-1}\right)$ was removed with residence time of $0.214 \mathrm{~min}$. 
To further understand the difference between the dyes removal efficiency, their 378 percentages removal efficiencies have been illustrated in Fig. 2 for different inlet 379 concentrations $\left(100-400 \mathrm{mg} \mathrm{L}^{-1}\right)$ and flow rates $\left(0.1-0.5 \mathrm{~L} \mathrm{~h}^{-1}\right)$. In all the conditions, the 380 removal yield of DR80 was higher than RR120, which was higher than RO16. For instance, the 381 removal efficiency equalled $23 \%, 48 \%$ and $99 \%$ at $400 \mathrm{mg} \mathrm{L}^{-1}$ and $0.5 \mathrm{~L} \mathrm{~h}^{-1}$. Moreover, the 382 average residence time for $1 \mathrm{mg} \mathrm{L}^{-1}$ of RO16, RR120 and DR80 was found to be $0.531,0.377$ 383 and 0.214 min respectively (Table SM-6), which corroborated the behaviour. This trend was in 384 agreement with the results obtained in batch mode, highlighting the influence of number of azo 385 groups on dye molecule considering that RO16, RR120 and DR80 have 1, 2 and 4 azo bonds, 386 respectively (Table 2). Thus, the higher the number of azo groups, the better the removal 387 efficiency. Interestingly, a linear relation was newly obtained between the number of azo bonds 388 and the removal efficiency as well as with the elimination capacity, giving slope values of 24.4 $389\left(\mathrm{R}^{2}=0.9988\right)$ and $70.0\left(\mathrm{R}^{2}=0.9988\right)$, respectively (Fig. 3a). Moreover, the increase of inlet 390 concentration makes increase the removal efficiencies for RO16 and RR120, while the removal 391 efficiencies of DR80 were around $97.5 \pm 2.5 \%$ for all the inlet concentrations. This means that 392 the kinetics were depending on the inlet concentrations. Another interesting feature is that the 393 removal efficiency was increasing with the flow rate, i.e when the retention time was decreasing, for all the dyes whatever their inlet concentrations. 
a

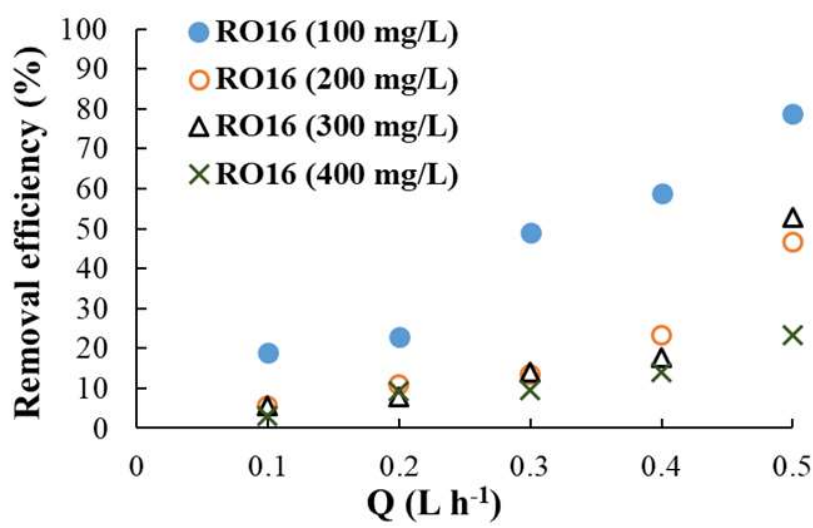

b
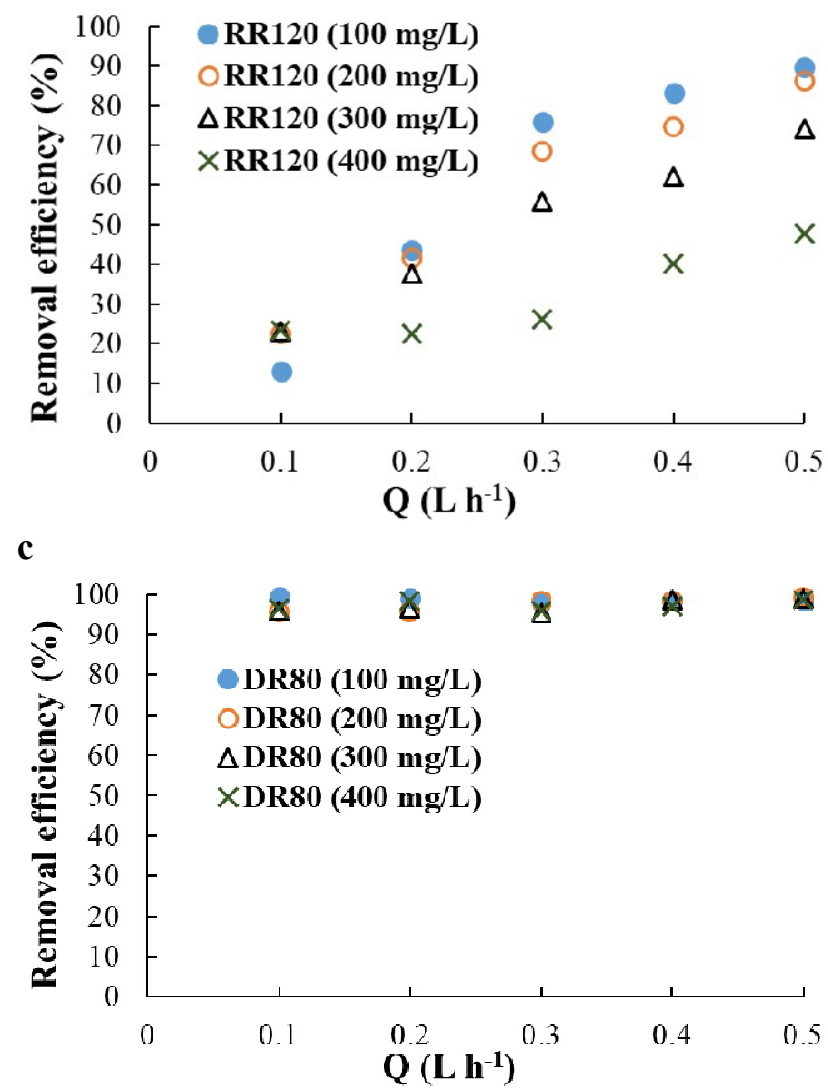

Fig. 2 Effect of flow rate and inlet concentration on the removal efficiency of RO16 (a), RR120 (b) and DR80 (c) dyes

To deeper understand the influence of flow rate, a comparison between the applied 397 current density $\left(j_{\text {appl }}\right)$ value $\left(47 \mathrm{~mA} \mathrm{~cm}^{-2}\right)$ with the initial limiting current density $\left(j_{\text {lim }}^{0}\right)$ values 398 has been performed by calculating the dimensionless current density $(\alpha)$, as defined by Eq. 399 (17) (Panizza et al., 2001): 
$400 \alpha=\frac{j_{\text {appl }}}{j_{\text {lim }}^{0}}$

401

In addition, $i_{\text {lim }}^{0}$ can be expressed as function of Faraday constant (F), the mass

402 transport coefficient $\left(\mathrm{k}_{\mathrm{m}}\right)$ and the inlet $\mathrm{COD}\left(\mathrm{COD}_{\text {in }}\right)$ Eq. (18) (Panizza et al., 2001):

$403 \quad i_{\text {lim }}^{0}=4 F k_{m} C O D_{\text {in }}$

$404 \quad$ By combining Eqs. (17) - (18), the following relation of $\alpha$ can be written Eq. (19):

$405 \quad \alpha=\frac{j_{a p p l}}{4 F k_{m} \operatorname{COD}_{i n}}$

406

In order to determine $\alpha$, the value of $\mathrm{k}_{\mathrm{m}}$ is required. $\mathrm{k}_{\mathrm{m}}$ has been estimated considering

407 the dimensionless Sherwood (Sh) number relation that can be defined as function of $\mathrm{k}_{\mathrm{m}}$, the

408 equivalent diameter $\left(d_{h}\right)$ and the diffusivity (D) Eq. (20) (Cañizares et al., 2006):

$409 S h=\frac{k_{m} d_{h}}{D}$

410

Sh number can also be generally expressed as function of dimensionless Reynolds (Re)

411 number and Schmidt (Sc) number. Eq. (21) (Anglada et al., 2010)), while Sc is defined through

412 Eq. (22) (Cañizares et al., 2006) and Re in a stirred tank reactor can be determined considering

413 Eq. (23) (Fitschen et al., 2019):

$414 S h=a R e^{b} S c^{c}$

$415 S c=\frac{v}{D}$

$416 \quad R e=\frac{d^{2} N}{v}$

417 where $v$ is the kinematic viscosity, $\mathrm{d}$ is the diameter of the stirrer, $\mathrm{N}$ is the rotation speed of the

418 stirrer.

419 By combining Eqs. (20) - (23), the general expression of $\mathrm{k}_{\mathrm{m}}$ is Eq. (24):

$420 \quad k_{m}=\frac{a}{d_{h}} D^{(1-c)} v^{(c-b)}\left(d^{2} N\right)^{b}$ 
422 follow by combining Eq. (19) and Eq. (24):

423

424

425

426

427

$$
\alpha=\frac{j_{a p p l}}{4 F C O D_{i n}} \frac{d_{h}}{a} D^{(c-1)} v^{(b-c)}\left(d^{2} N\right)^{-b}
$$

In this work, the values of $\mathrm{d}_{\mathrm{h}}, \mathrm{d}, \mathrm{D}, \mathrm{N}, \mathrm{v}, \mathrm{a}, \mathrm{b}$ and c constants were considered equalled to $10.5 \mathrm{~cm}, 2 \mathrm{~cm}, 10^{-9} \mathrm{~m}^{2} \mathrm{~s}^{-1}$ (Scialdone et al., 2012b), $100 \mathrm{rpm}, 8.917 \times 10^{-7} \mathrm{~m}^{2} \mathrm{~s}^{-1}$ at $25^{\circ} \mathrm{C}$ (Engineering ToolBox, 2004), 0.228 (Selman and Tobias, 1978), 0.66 (Selman and Tobias, 1978) and 0.33 (Selman and Tobias, 1978), respectively. A $k_{m}$ value of $1.710^{-6} \mathrm{~m} \mathrm{~s}^{-1}$ was therefore obtained in this study. This value is in the same range of values given in literature for a stirred tank reactor $\left(\sim 5.910^{-6} \mathrm{~m} \mathrm{~s}^{-1}\right)$ (dos Santos et al., 2014; Mousset et al., 2019b; Rocha et al., 2012). The $\mathrm{COD}_{\text {in }}$ values used for $\alpha$ calculation are reported in Table SM-7. The results of dimensionless current density as function of the dyes and their inlet concentrations are displayed in Fig. 3b. In all the cases, $\alpha$ was ranging from 18 to 102 and was always higher than 1, which means that $j_{a p p l}$ was always higher than $j_{\text {lim }}^{0}$. It can therefore be concluded that the kinetics were under mass transport control all along the treatment (Mousset et al., 2019a; Panizza et al., 2001). Knowing that the flow rate has an influence on $\mathrm{k}_{\mathrm{m}}$, it means that increasing $\mathrm{Q}$ make increase $\mathrm{k}_{\mathrm{m}}$ and therefore enhance the kinetics, since it is under mass transport control. Thus, it explains the increase of removal efficiency with an increase of flow rate in Fig. 4. 
a

442

443

444

445

446

447

448

449

450

451

452

453

454

455

456

457

458

459

460

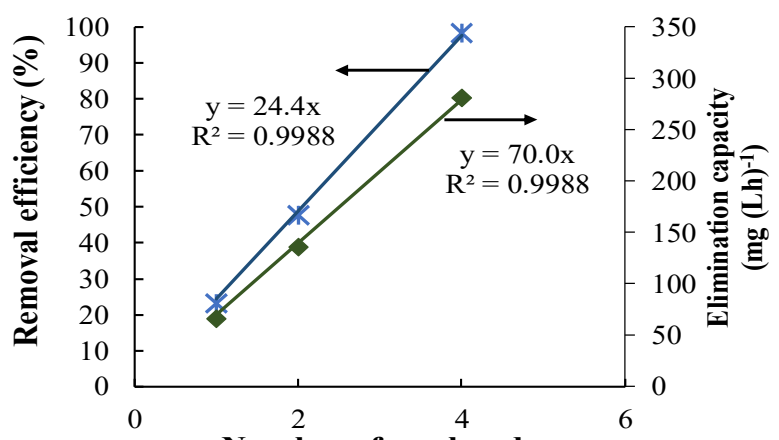

Number of azo bonds b

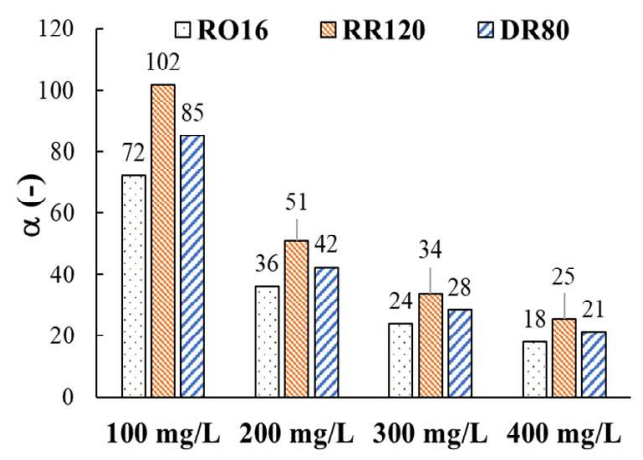

Fig. 3 Influence of number of azo bonds on the dyes removal efficiency and elimination capacity at $400 \mathrm{mg} \mathrm{L}^{-1}$ and $0.5 \mathrm{~L} \mathrm{~h}^{-1}$ (a), dimensionless current density as function of inlet concentration of RO16, RR120 and DR80 dyes (b)

To further assess the efficiency of the process, the current efficiency (CE) has been calculated considering a continuous mode using Eq. (26) (Scialdone et al., 2012a):

$C E(\%)=100 \times \frac{n F C_{i n} X Q}{j_{a p p l} A}$

where $\mathrm{A}$ is the immerged surface area of the electrode $\left(17 \mathrm{~cm}^{2}\right), \mathrm{X}$ is the conversion yield $\left(\left(\mathrm{C}_{\mathrm{in}}-\right.\right.$ $\left.\mathrm{C}_{\text {out }}\right) / \mathrm{C}_{\text {in }}$ ) and $\mathrm{n}$ is the number of electron(s) required for the conversion of the dye into carbon dioxide by electrochemical combustion reaction that can be written as follow for RO16 (Eq. (27)), RR120 (Eq. (28)) and DR80 (Eq. (29)):

$\mathrm{C}_{20} \mathrm{H}_{17} \mathrm{O}_{11} \mathrm{~N}_{3} \mathrm{~S}_{3}+41 \mathrm{H}_{2} \mathrm{O} \rightarrow 20 \mathrm{CO}_{2}+3 \mathrm{NH}_{3}+3 \mathrm{H}_{2} \mathrm{SO}_{4}+84 \mathrm{H}^{+}+84 e^{-}$

$\mathrm{C}_{44} \mathrm{H}_{24} \mathrm{O}_{20} \mathrm{~N}_{14} \mathrm{Cl}_{2} \mathrm{~S}_{6}+92 \mathrm{H}_{2} \mathrm{O} \rightarrow 44 \mathrm{CO}_{2}+14 \mathrm{NH}_{3}+2 \mathrm{HCl}+6 \mathrm{H}_{2} \mathrm{SO}_{4}+152 \mathrm{H}^{+}+152 e^{-}$

$\mathrm{C}_{45} \mathrm{H}_{26} \mathrm{O}_{21} \mathrm{~N}_{10} \mathrm{~S}_{6}+93 \mathrm{H}_{2} \mathrm{O} \rightarrow 45 \mathrm{CO}_{2}+10 \mathrm{NH}_{3}+6 \mathrm{H}_{2} \mathrm{SO}_{4}+170 \mathrm{H}^{+}+170 e^{-}$

From Eqs. (27) - (29), it can be noted that the values of $\mathrm{n}$ for RO16, RR120, and DR80 were 84,152 and 170 , respectively. The specific electric energy consumption ( $\left.\mathrm{E}_{\text {specific }}\right)$ was also estimated in continuous mode (Eq. (30)) (Mousset et al., 2018):

$E_{\text {specific }}=\frac{E_{\text {cell } I}}{C_{\text {in } X Q}}$ 
a

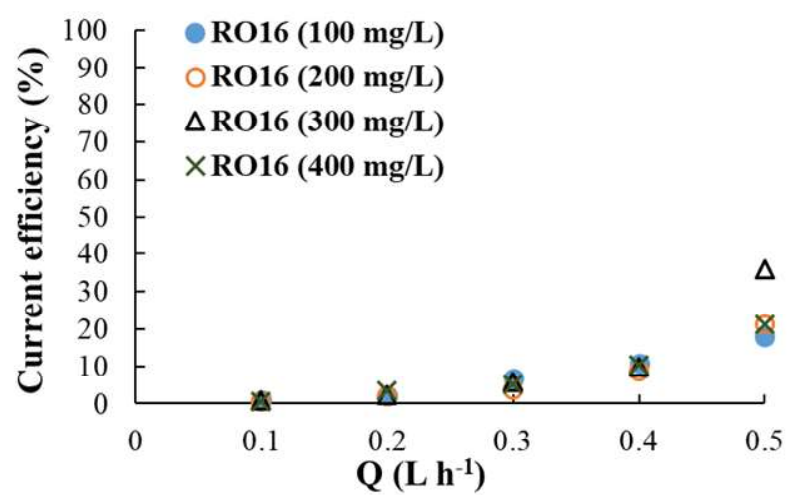

b

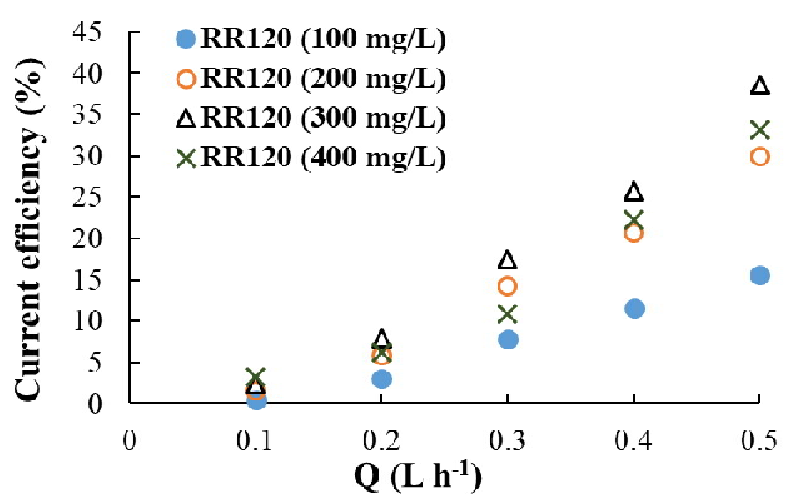

c

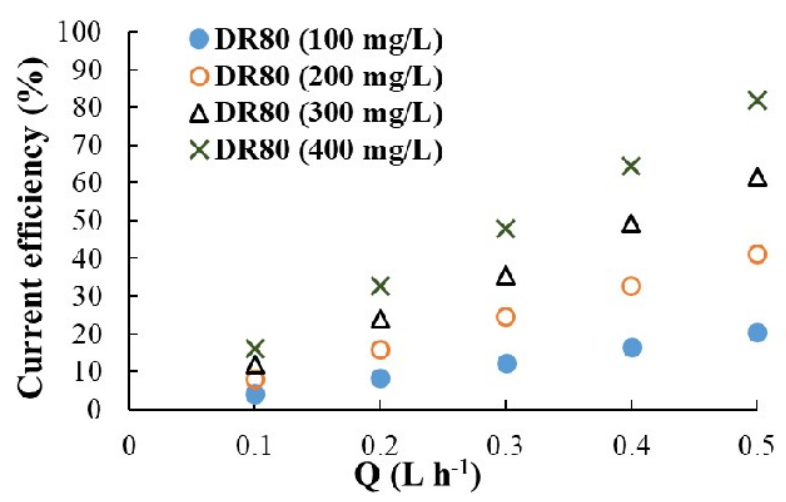

d
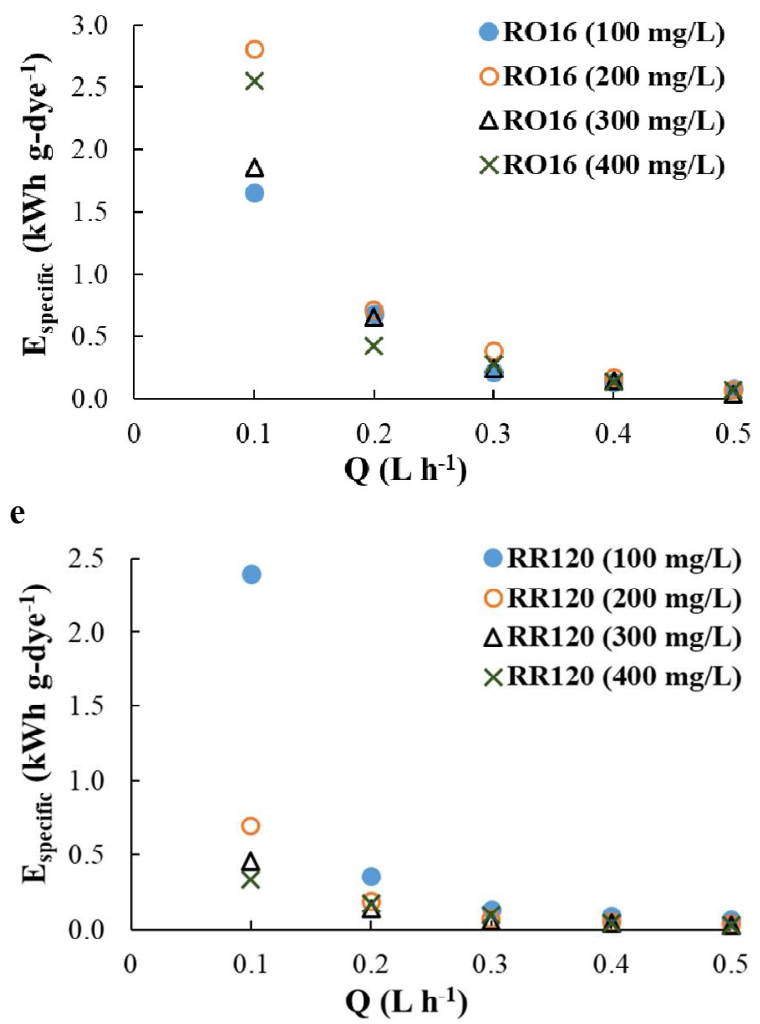

f

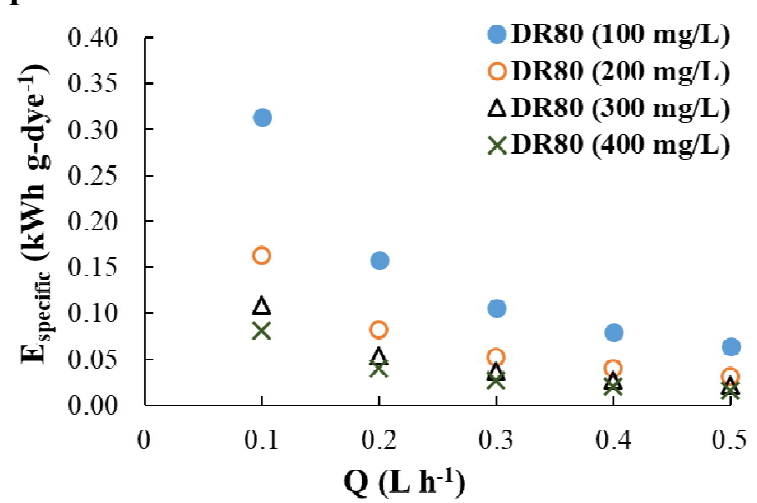

462 rate and inlet concentration. The following rank of CE was obtained (from the highest to the 468 lowest): DR80 (4\% - 82\%) > RR120 (0.45\% - 33\%) > RO16 (0.56\% - 21\%), whatever the inlet 469

Fig. 4 Effect of flow rate and inlet concentration on the current efficiency (a, b, c) and the specific energy requirement (d, e, f) to remove RO16 (a, d), RR120 (b, e) and DR80 (c, f) dyes Both current efficiency and specific energy have been plotted in Fig. 4 as function of flow concentration and flow rate. This trend was in agreement with the removal efficiencies (Fig. 2). 
The energy requirement followed the opposite relation order (from the highest to the lowest

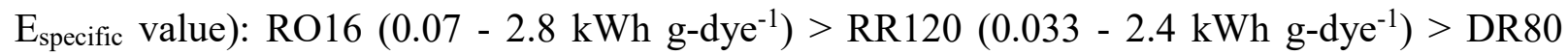
$\left(0.016-0.31 \mathrm{kWh}\right.$ g-dye $\left.\mathrm{d}^{-1}\right)$. At optimal condition for complete decolorization, the energy consumption was around $6 \mathrm{kWh} \mathrm{m}^{-3}$ in this work against $11 \mathrm{kWh} \mathrm{m}^{-3}$ with aluminium anode obtained in a previous study (Arslan-Alaton et al., 2008). This demonstrates the interest of using stainless steel anode compared to aluminium electrode.

In addition, $\mathrm{CE}$ and $\mathrm{E}_{\text {specific }}$ were generally raising and decreasing respectively with the inlet concentration, as a further confirmation of the kinetics dependency with the inlet concentration. Moreover, $\mathrm{CE}$ values were increasing with the flow rate, while $\mathrm{E}_{\text {specific }}$ values were decreasing, due to mass transport control.

\section{CONCLUSIONS}

This study investigates the electrochemical decomposition of synthetic azo dyes (RO16, RR120 \& DR80) using a continuous electrochemical reactor containing stainless steel electrodes. The interaction between the influencing parameters was determined using RSM. The results obtained from the transformed model showed that the optimum operating conditions for obtaining maximum percentage of dye decolorization were $\mathrm{pH}$ of 11.0 electrolyte concentration of $0.5 \mathrm{M}$. The elimination capacity of electrochemical reactor was studied with respect to residence time for the continuous removal of azo dyes. The effect of other process parameters such as mass transport coefficient, dimensionless current density, current efficiency and specific energy were evaluated. The $\alpha$ value given for the process shows that the global kinetics was under mass transport control. Current efficiency (\%) increased for dyes with maximum number of azo bonds (irrespective of the initial dye concentration and flow rate) and the condition was vice versa with respect to specific energy calculation. From the kinetic analysis and transport modelling, in case of both the batch and continuous process, 
495 it is evident that the percentage of removal efficiency is directly linked to the initial dye 496 concentration, $\mathrm{pH}$, flow rate and number of azo bonds. Thus the model developed in this

497 research work shows a paramount feasibility of using stainless steel electrode for the continuous electrochemical decomposition of textile effluents containing azo dyes. Moreover, the experimental understanding on mass transport coefficient, dimensionless current density, current efficiency and specific energy give interesting information towards the efficiency and the reactor design optimization for upscaling the process. As a next step, since the kinetics seems to be under mass transport control, a further optimization of the reactor design would even increase the current performance, by intensifying the mass transport between the bulk and the surfaces of electrodes.

\section{ACKNOWLEDGEMENT}

The authors are grateful to Prof. Anant Achary, Department of Biotechnology, Kamaraj College of Engineering \& Technology for providing us valuable suggestions in approaching this research work.

\section{REFERENCES}

Amani-ghadim, A.R., Aber, S., Olad, A., Ashassi-sorkhabi, H., 2013. Optimization of electrocoagulation process for removal of an azo dye using response surface methodology and investigation on the occurrence of destructive side reactions. Chem. Eng. Process. Process Intensif. 64, 68-78. https://doi.org/10.1016/j.cep.2012.10.012

Anglada, A., Urtiaga, A.M., Ortiz, I., 2010. Laboratory and pilot plant scale study on the electrochemical oxidation of landfill leachate. J. Hazard. Mater. 181, 729-35. https://doi.org/10.1016/j.jhazmat.2010.05.073

Aquino, J.M., Rocha-Filho, R.C., Rodrigo, M.A., Sáez, C., Cañizares, P., 2013. 
Electrochemical degradation of the Reactive Red 141 dye using a boron-doped diamond anode. Water. Air. Soil Pollut. 224. https://doi.org/10.1007/s11270-012-1397-9

Arslan-Alaton, I., Kabdaşli, I., Hanbaba, D., Kuybu, E., 2008. Electrocoagulation of a real reactive dyebath effluent using aluminum and stainless steel electrodes. J. Hazard. Mater. 150, 166-173. https://doi.org/10.1016/j.jhazmat.2007.09.032

Bassyouni, D.G., Hamad, H.A., El-ashtoukhy, E.Z., Amin, N.K., El-latif, M.M.A., 2017. Comparative performance of anodic oxidation and electrocoagulation as clean processes for electrocatalytic degradation of diazo dye Acid Brown 14 in aqueous medium. J. Hazard. Mater. 335, 178-187. https://doi.org/10.1016/j.jhazmat.2017.04.045

Brahmi, L., Kaouah, F., Boumaza, S., Trari, M., 2019. Response surface methodology for the optimization of acid dye adsorption onto activated carbon prepared from wild date stones. Appl. Water Sci. 9. https://doi.org/10.1007/s13201-019-1053-2

Brillas, E., Martínez-Huitle, C.A., 2015. Decontamination of wastewaters containing synthetic organic dyes by electrochemical methods. An updated review. Appl. Catal. B Environ. 166-167, 603-643. https://doi.org/10.1016/j.apcatb.2014.11.016

Cañizares, P., Marcos, I.F. De, Rodrigo, M.A., Lobato, J., 2006. Measurement of MassTransfer Coefficients by an Electrochemical Technique. J. Chem. Educ. 83, 1204-1207. https://doi.org/10.1021/ed083p1204

Correia, V.M., Stephenson, T., Judd, S.J., 1994. Characterisation of textile wastewaters - a review. Environ. Technol. (United Kingdom) 15, 917-929. https://doi.org/10.1080/09593339409385500

dos Santos, E.V., Sena, S.F.M., da Silva, D.R., Ferro, S., De Battisti, A., Martínez-Huitle, C.A., 2014. Scale-up of electrochemical oxidation system for treatment of produced water generated by Brazilian petrochemical industry. Environ. Sci. Pollut. Res. 21, 8466-8475. https://doi.org/10.1007/s11356-014-2779-x 
Fitschen, J., Maly, M., Rosseburg, A., Wutz, J., Wucherpfennig, T., Schlüter, M., 2019. Influence of Spacing of Multiple Impellers on Power Input in an Industrial-Scale Aerated Stirred Tank Reactor. Chemie-Ingenieur-Technik 91, 1794-1801. https://doi.org/10.1002/cite.201900121

Gürses, A., Açıkyıldız, M., Güneş, K., Gürses, M.S., 2016. "Dyes and Pigments: Their Structure and Properties" in SpringerBriefs in Green Chemistry for Sustainability 13-29. https://doi.org/10.1007/978-3-319-33892-7

Hakizimana, J.N., Gourich, B., Chafi, M., Stiriba, Y., Vial, C., Drogui, P., Naja, J., 2017. Electrocoagulation process in water treatment: A review of electrocoagulation modeling approaches. Desalination 404, 1-21. https://doi.org/10.1016/j.desal.2016.10.011

Hasanbeigi, A., Price, L., 2015. A technical review of emerging technologies for energy and water ef fi ciency and pollution reduction in the textile industry. J. Clean. Prod. 95, 30-44. https://doi.org/10.1016/j.jclepro.2015.02.079

Holkar, C.R., Jadhav, A.J., Pinjari, D. V, Mahamuni, N.M., Pandit, A.B., 2016. A critical review on textile wastewater treatments : Possible approaches. J. Environ. Manage. 182, 351-366. https://doi.org/10.1016/j.jenvman.2016.07.090

Jegan Durai, N., Gopalakrishna, G.V.T., Padmanaban, V.C., Selvaraju, N., 2020. Oxidative removal of stabilized landfill leachate by Fenton's process: Process modeling, optimization \& analysis of degraded products. RSC Adv. 10, 3916-3925. https://doi.org/10.1039/c9ra09415f

Michaelis, L., 1935. Semiquinones, the intermediate steps of reversible organic oxidationreduction. Chem. Rev. 16, 243-286. https://doi.org/10.1021/cr60054a004

Mohan, N., Balasubramanian, N., Basha, C.A., 2007. Electrochemical oxidation of textile wastewater and its reuse. J. Hazard. Mater. 147, 644-651. https://doi.org/10.1016/j.jhazmat.2007.01.063 
Mousset, E., Pechaud, Y., Oturan, N., Oturan, M.A., 2019a. Charge transfer/mass transport competition in advanced hybrid electrocatalytic wastewater treatment: Development of a new current efficiency relation. Appl. Catal. B Environ. 240, 102-111. https://doi.org/10.1016/j.apcatb.2018.08.055

Mousset, E., Puce, M., Pons, M.-N., 2019b. Advanced electro-oxidation with boron-doped diamond for acetaminophen removal from real wastewater in a microfluidic reactor Kinetics and mass transfer studies. ChemElectroChem 6, 2908-2916. https://doi.org/10.1002/celc.201900182

Mousset, E., Quackenbush, L., Schondek, C., Gerardin-Vergne, A., Pontvianne, S., Kmiotek, S., Pons, M.N., 2020. Effect of homogeneous Fenton combined with electron transfer on the fate of inorganic chlorinated species in synthetic and reclaimed municipal wastewater. Electrochim. Acta 334. https://doi.org/10.1016/j.electacta.2019.135608

Mousset, E., Wang, Z., Olvera-Vargas, H., Lefebvre, O., 2018. Advanced electrocatalytic pretreatment to improve the biodegradability of real wastewater from the electronics industry - A detailed investigation study. J. Hazard. Mater. 360, 552-559. https://doi.org/10.1016/j.jhazmat.2018.08.023

Muniyasamy, A., Sivaporul, G., Gopinath, A., Lakshmanan, R., Altaee, A., Achary, A., Velayudhaperumal Chellam, P., 2020. Process development for the degradation of textile azo dyes (mono-, di-, poly-) by advanced oxidation process - Ozonation: Experimental \& partial derivative modelling approach. J. Environ. Manage. 265. https://doi.org/10.1016/j.jenvman.2020.110397

Nidheesh, P.V., Divyapriya, G., Oturan, N., Trellu, C., Oturan, M.A., 2019. Environmental Applications of Boron-Doped Diamond Electrodes: 1. Applications in Water and Wastewater Treatment. ChemElectroChem 6, 2124-2142. https://doi.org/10.1002/celc.201801876 
601

602

603

604

605

606

607

608

609

610

611

612

613

614

615

616

617

618

619

Mousset, E., Oturan, N., Oturan, M.A., 2018. An unprecedented route of [rad]OH radical reactivity evidenced by an electrocatalytical process: Ipso-substitution with perhalogenocarbon compounds. Appl. Catal. B Environ. 226, 135-146. https://doi.org/10.1016/j.apcatb.2017.12.028

Padmanaban, V.C., Geed, S.R.R., Achary, A., Singh, R.S., 2016. Kinetic studies on degradation of Reactive Red 120 dye in immobilized packed bed reactor by Bacillus cohnii

RAPT1.

Bioresour.

Technol.

213,

$39-43$. https://doi.org/10.1016/j.biortech.2016.02.126

Padmanaban, V.C., Selvaraju, N., Vasudevan, V.N., Achary, A., 2018. Augmented radiolytic (60Co) degradation of direct red 80 (Polyazo dye): optimization, reaction kinetics \& Gvalue interpretation. React. Kinet. Mech. Catal. 125, 433-447. https://doi.org/10.1007/s11144-018-1410-4

Panizza, M., Cerisola, G., 2009. Direct and mediated anodic oxidation of organic pollutants. Chem. Rev. 109, 6541-6569. https://doi.org/10.1021/cr9001319

Panizza, M., Michaud, P.A., Cerisola, G., Comninellis, C., 2001. Anodic oxidation of 2naphthol at boron-doped diamond electrodes. J. Electroanal. Chem. 507, 206-214. https://doi.org/10.1016/S0022-0728(01)00398-9

Rocha, J.H.B., Solano, A.M.S., Fernandes, N.S., da Silva, D.R., Peralta-Hernandez, J.M., Martínez-Huitle, C.A., 2012. Electrochemical Degradation of Remazol Red BR and Novacron Blue C-D Dyes Using Diamond Electrode. Electrocatalysis 3, 1-12. https://doi.org/10.1007/s12678-011-0070-1

Schneider, K., Hafner, C., Jäger, I., 2004. Mutagenicity of textile dye products. J. Appl. Toxicol. 24, 83-91. https://doi.org/10.1002/jat.953

Scialdone, O., Galia, A., Guarisco, C., La Mantia, S., 2012a. Abatement of 1,1,2,2tetrachloroethane in water by reduction at silver cathode and oxidation at boron doped 
diamond anode in micro reactors. Chem. Eng. J. 189-190, 229-236. https://doi.org/10.1016/j.cej.2012.02.062

Scialdone, O., Galia, A., Randazzo, S., 2012b. Electrochemical treatment of aqueous solutions containing one or many organic pollutants at boron doped diamond anodes. Theoretical modeling and experimental data. Chem. Eng. J. 183, 124-134. https://doi.org/10.1016/j.cej.2011.12.042

Selman, J.R., Tobias, C.W., 1978. Mass-Transfer Measurements by the Limiting-Current Technique. Adv. Chem. Eng. 10, 211-318.

Shahnaz, T., S., M.M.F., V.C., P., Narayanasamy, S., 2020a. Surface modification of nanocellulose using polypyrrole for the adsorptive removal of Congo red dye and chromium in binary mixture. Int. J. Biol. Macromol. 151, 322-332. https://doi.org/10.1016/j.ijbiomac.2020.02.181

Shahnaz, T., Sharma, V., Subbiah, S., Narayanasamy, S., 2020b. Multivariate optimisation of $\mathrm{Cr}$ (VI), $\mathrm{Co}$ (III) and $\mathrm{Cu}$ (II) adsorption onto nanobentonite incorporated nanocellulose/chitosan aerogel using response surface methodology. J. Water Process Eng. 36. https://doi.org/10.1016/j.jwpe.2020.101283

Sharma, V., Shahnaz, T., Subbiah, S., Narayanasamy, S., 2020. New Insights into the Remediation of Water Pollutants using Nanobentonite Incorporated Nanocellulose Chitosan Based Aerogel. J. Polym. Environ. 28, 2008-2019. https://doi.org/10.1007/s10924-020-01740-9 